\section{Using Waste Heat for External Processes}

The temperature of exhaust gases from fuelfired industrial processes depends mainly on the process temperature and the waste heat recovery method. Figure 1 shows the heat lost in exhaust gases at various exhaust gas temperatures and percentages of excess air. Energy from gases exhausted from higher temperature processes (primary processes) can be recovered and used for lower temperature processes (secondary processes). One example is to generate steam using waste heat boilers for the fluid heaters used in petroleum crude processing. In addition, many companies install heat exchangers on the exhaust stacks of furnaces and ovens to produce hot water or to generate hot air for space heating.

Before attempting to use energy from higher temperature flue gases in lower temperature processes, engineers should take the following technical issues into consideration:

- Nature or quality of the flue gases. Flue gases from the primary processes should be clean and free of contaminants such as corrosive gases and particulates.

Contaminants pose special handling problems for the gases and might affect the quality of work in the secondary process.

- Temperature of primary process flue gases. The temperature difference between the primary and secondary process should be high enough (at least $93^{\circ} \mathrm{C}$ ), and there should be a sufficient amount of usable waste heat.

- Matching the heat demand of the secondary process with the heat supply from the primary process. The heat supply from the primary process should be sufficiently high to meet a reasonably high percentage of the secondary process heat demand.

- Matching the timing of the heat supply from the primary process and the heat demand in the secondary process.

- Placement of primary and secondary heating equipment. The closer the primary and secondary process can be situated, the better.

Figure 2 shows some heating processes that commonly use waste heat from a higher temperature process, and the approximate range of waste gas temperatures they require. Sometimes lower temperature gases can be used if the heat recovery device is deliberately oversized.

\section{Example}

A plant uses a furnace with a firing rate of $10.6 \mathrm{GJ} / \mathrm{hr}$, which discharges flue gases at $760^{\circ} \mathrm{C}$ (primary process). The plant also has a drying oven that operates at $204^{\circ} \mathrm{C}$ and requires $2.6 \mathrm{GJ} / \mathrm{hr}$ of heat (secondary process). The recoverable heat can be estimated using Figure 1 . At $760^{\circ} \mathrm{C}$, the heat content of the exhaust gases (at $10 \%$ excess air) is about $42 \%$ of the heat furnace input. Again using Figure 1, the heat content of exhaust gases at $204^{\circ} \mathrm{C}$ is approximately $20 \%$ (at $10 \%$ excess air). The approximate amount of heat that can be saved is $42 \%-20 \%=$ $22 \%$ of the heat input to the primary process. The net heat available for the secondary process is approximately $0.22 \times 10.6 \mathrm{GJ} / \mathrm{hr}=$ $2.3 \mathrm{GJ} / \mathrm{hr}$. Actual savings would be greater than this because the available heat at the

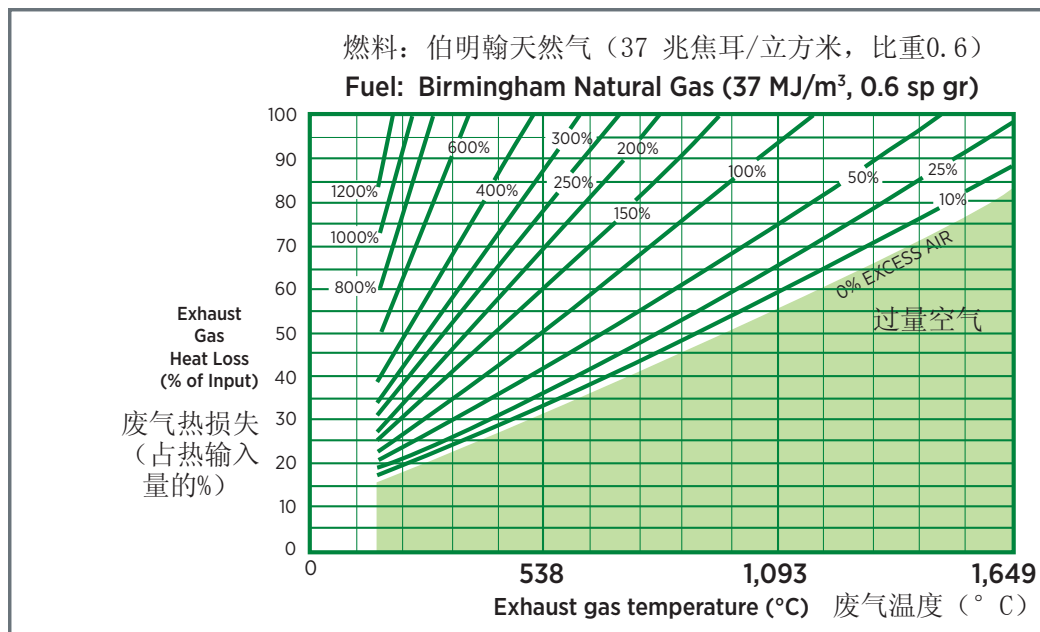

Figure 1. Heat loss in exhaust gases at various exhaust gas temperature and excess air percents ${ }^{1}$ 图 1. 在不同废气温度和过量空气比例状态下, 废气带走的热损失

\section{Suggested Actions}

Questions to ask when evaluating the use of waste gases for heating secondary processes:

1. Is there a less expensive way to heat the secondary process?

2. Is the temperature of the flue gases high enough to heat the secondary process?

3. Do the flue gases contain enough transferable energy?

4. Are the flue gases compatible with the secondary process (as to cleanliness, corrosiveness, etc.)?

5. Can the primary process deliver energy to the secondary process in time?

6. Are the two processes close enough together to avoid excessive heat losses during waste gas transport?

7. Will the flue gases leave the secondary process at a high enough temperature to avoid problems with moisture condensation?

8. Can the exhaust ductwork and secondary process be designed to avoid excessive pressure resistance to the flue gases, or are additional means like exhaust fans necessary?

\section{Resources}

See also the ASM Handbook, Volumes 1 (1990) and 2 (1991), Materials Park, OH: ASM International; Combustion Technology Manual, Fifth Edition, Cincinnati, OH: Industrial Heating Equipment Association (IHEA), 1994; Handbook of Applied Thermal Design, E.C. Guyer and D.L. Brownell, eds., London: Taylor \& Francis Group, 1999.

\section{U.S. Department of Energy-}

For additional information on process heating system efficiency, to obtain DOE's publications and Process Heating Assessment and Survey Tool (PHAST) software, or learn more about training, visit the BestPractices Web site at www.eere. energy.gov/industry/bestpractices.

$204^{\circ} \mathrm{C}$ exhaust gas temperature is approximately $80 \%$ (see Figure 1 in Process Heating Tip Sheet \#9, Load Preheating Using Flue Gases from a Fuel-Fired Heating System). The actual savings for the oven are thus $2.3 / 0.8=2.9 \mathrm{GJ} / \mathrm{hr}$.

In this case, there is more than enough heat to meet the heat demand for the drying oven. It would be necessary to use additional heat in the oven if the exhaust gas heat from the furnace were not sufficient to meet the oven heat demand. At a fuel cost of $\$ 7.50$ per GJ, the company can save $\$ 22.00$ in fuel costs per hour. Assuming 8,000 hours of operation per year, annual savings are $\$ 175,000$. 


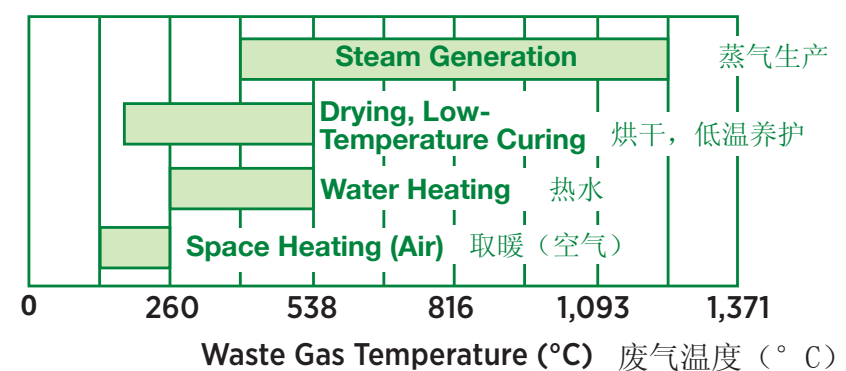

Figure 2. Typical secondary processes and approximate exhaust temperatures ${ }^{2}$

图2: 典型的次要工艺和废气温度的大致范围 ${ }^{2}$

余热的利用

使用燃料的工艺排放出废气，废气的温度 主要取决于工艺的温度以及余热回收的方 法。图1显示了在不同的废气温度和不同比 例的过量空气下，废气带走的热损失。高 温工艺 (主要工艺) 排放出的废气中的能 源可以被回收, 并用于低温工艺（次要工 艺）。例如，原油加工工艺中的流体加热 器的废热可以用于废热锅炉生产蒸气。此 外, 许多公司在熔炉和锅炉的排气烟图上 安装了热交换器, 利用余热生产热水或生 产取暖所用的热空气。

在尝试将高温烟气的能源用于低温工艺之 前, 工程师应该考虑以下几个技术问题:

- 烟气的性质或质量。主要工艺的烟气应 是干净的, 并没有如腐蚀性气体或微粒 等无污染物。污染物会给气体的处理带 来特殊的问题, 而且可能影响次要工艺 的工作质量。

- 主要工艺的烟气温度。主要工艺和次 要工艺的温度差应该足够大（至少

$\left.93^{\circ} \mathrm{C}\right)$, 而且应该有足够的可用余热 量。

- 将次要工艺的热需求与主要工艺的热供 给相匹配。主要工艺的热供给应该足够 高, 从而满足次要工艺热需求的较高的 比例。

- 将主要工艺热供给的时间与次要工艺的 热需求相匹配。

- 主要和次要工艺设备的位置摆放。在满 足条件的情况下，主要和次要工艺间的 距离越近越好。

图2显示了一些经常利用来自高温工艺余热 的加热工艺, 以及它们需要的废气温度的 大致范围。有时, 如果特意扩大余热回收 的设备, 也能利用温度更低的废气。
建议采取的节能行动

当评估余热是否能用于加热次要工艺时, 请考 虑以下问题:

1. 是否还有更便宜的方法来加热次要工艺?

2. 用于加热次要工艺的烟气温度是否足够高?

3. 烟气中是否含有足够的可转移的能源?

4. 烟气是否与次要工艺的要求相符合 (如烟气 的清洁度和腐蚀程度等）?

5. 主要工艺可以及时将能源送至次要工艺吗?

6. 主要工艺与次要工艺的位置是否足够近, 从 而避免在余热传输中额外的热损失?

7. 次要工艺排出的烟气的温度是否足够高, 从 而避免水分凝结带来的问题?

8. 是否可以将废气管道和次要工艺设计得避免 对烟气出现过多的压力阻力? 或者, 是否需 要额外手段（如排风机）?

\section{资源}

参见ASM Handbook, Volumes 1 (1990) and 2 (1991), Materials Park, OH: ASM International; Combustion Technology Manual, Fifth Edition, Cincinnati, $\mathrm{OH}$ : Industrial Heating Equipment Association (IHEA), 1994; Handbook of Applied Thermal Design, E.C. Guyer and D.L. Brownell, eds., London: Taylor \& Francis Group, 1999

美国能源部一一如需进一步了解过程加热系 统能效的信息, 获取美国能源部的报告以及 过程加热评估工具 (PHAST工具), 或想进 一步了解有关培训，请访问美国能源部工 业技术项目 “最佳实践” 的网站www.eere energy.gov/industry/bestpractices。

\section{示例}

工厂熔炉的燃烧率为 10.6 吉焦 (GJ) / 小 时, 排出的烟气温度为 $760^{\circ} \mathrm{C}$ (主要工 艺）。工厂还有一台干燥箱, 运行温度为 $204^{\circ} \mathrm{C}$, 每小时需要 2.6 吉焦的热量 (次 要工艺）。通过图1计算出可回收的热量。 在 $760^{\circ} \mathrm{C}$ 时，烟气（过量空气为 $10 \%$ ）中的 热含量为熔炉热输入的 $40 \%$ 。再次利用图1 , 可得知当烟气温度为 $204^{\circ} \mathrm{C}$ 时, 烟气中
的热含量大约热输入的20\% (过量空气为 10\%）。能够节约的热量大约为 $42 \%-20 \%=$ $22 \%$, 即大约可节约主要工艺热量总输入的 $22 \%$ 。供次要工艺所用的净热值大约是 0.22 x 10.6吉焦/小时 $=2.3$ 吉焦/小时。实际 的节能量要比这个数值高, 因为当烟气温 度为 $204^{\circ} \mathrm{C}$ 时, 有效热量大约为 $80 \%$ （见过 程加热建议报告\#9 “利用加热系统的烟气 预热入炉料” 中的图1）。干燥箱实际的节 能量即为 $2.3 / 0.8=2.9$ 吉焦/小时。

在这个例子的情况下，有足够的余热满足 干燥箱的热需求。在有些情况下, 当熔炉 的余热无法完全满足干燥箱的热需求时, 可能有必要利用额外的热量。当燃料价格 为 $\$ 7.50$ 美元/吉焦时, 公司每小时可节省 燃料成本 $\$ 22.00$ 美元。假设每年运行 8,000 小时，每年可节省 $\$ 175,000$ 美元。

BestPractices is part of the Industrial Technologies Program Industries of the Future strategy, which helps the country's most energy-intensive industries improve their competitiveness. BestPractices brings together emerging technologies and best energy-management practices to help companies begin improving energy efficiency, environmental performance, and productivity right now.

BestPractices emphasizes plant systems, where significant efficiency improvements and savings can be achieved. Industry gains easy access to near-term and long-term solutions for improving the performance of motor, steam, compressed air, and process heating systems. In addition, the Industrial Assessment Centers provide comprehensive industrial energy evaluations to small- and medium-size manufacturers.

“最佳实践（BestPractices）”是工业技术 项目 “未来产业” 战略的一部分, 它可帮 助高能耗的产业提高竞争力。“最佳实践 （BestPractices）”提供新兴技术以及最佳能 源管理实践方面的信息, 帮助公司改善能源效 率, 提高环保绩效, 并提升生产效率。

“最佳实践（BestPractices）”强调工厂系统 的重要性, 从工厂系统的角度实现能效的大幅 提高, 并获得显著的节能量。企业可获得提 高风机、蒸汽系统、空气压缩系统和过程加 热系统绩效的近期和长期的解决方案。此外, 工业评估中心向中小型企业提供全面的工业能 源评价。

${ }^{1}$ Calculations by Richard Bennett, Janus Technology Group. 计算结果来自Janus Technology Group的Richard Bennett。

${ }^{2}$ Figure by Richard Bennett, Janus Technology Group. 此图来自Janus Technology Group的Richard Bennett。

\section{EMTERTY}

Energy Efficiency \&

Renewable Energy
EERE Information Center

能效和可再生能源信息中心

1-877-EERE-INFO (1-877-337-3463)

www.eere.energy.gov/informationcenter

Printed with a renewable-source ink on paper containing at least $50 \%$ wastepaper, including $10 \%$ post consumer waste.

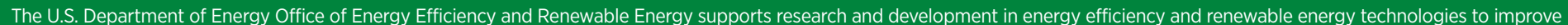

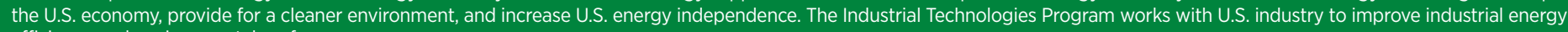
efficiency and environmental performance. 